\title{
Wage indexation and industrial relations: a comparison of recent experience in Israel and Australia
}

\author{
Amira Galin and Russell D. Lansbury*
}

Australia and Israel both have centralised machinery for the determination of national wage policy. In Australia, the Conciliation and Arbitration Commission holds an annual national wage hearing. In Israel, a national framework agreement for determining wage levels is bargained and signed by the parties every two years. In addition, both countries have periodical arrangements for adjusting wages as a result of movement in the cost of living. This article compares the indexation arrangements of the two countries and analyses their impact on industrial relations.

\section{Introduction}

Rapid economic change, a relatively high rate of inflation and increasing industrial unrest have been common features of life in the advanced industrialised countries in recent years. A number of these countries have sought to minimise fluctuations in real income, while maintaining centralised control over wage movements, through the indexation of wages or personal taxation or a combination of both. Israel and Australia are countries with a long history of experimentation with various forms of wage indexation. A comparison of their experience, particularly in recent years, provides an opportunity to analyse the impact of indexation policies on the industrial relations system.

It is notoriously difficult to compare wages policy and industrial relations between countries which have different economic, social and political environments. Nevertheless, there exist a number of similarities between the industrial relations systems in Australia and Israel. First, both have highly centralised systems of wage determination. In Australia, this is due to the role of the Conciliation and Arbitration Commission in the administration of the national wages policy. In Israel, centralisation is the product of the national framework agreement which is negotiated every two years between the Federation of Labour (the Histadruth) and the National Employers Federation. In both countries, however, considerable differences exist between minimum wages levels which are agreed centrally and the actual wages which are paid above the awards (in Australia) or in excess of the agreement (in Israel). Secondly, like many other advanced industrialised countries, Australia and Israel have experienced a growing rate of industrial disputation in recent years. The mass media in both countries assign considerable importance to the incidence

* Amira Galin is Senior Lecturer in Industrial Relations, Faculty of Management, University of Tel Aviv, Israel, and Russell D. Lansbury is Associate Professor in Management, School of Economic and Financial Studies, Macquarie University, New South Wales, Australia. An earlier version of this paper was presented to the Fourth Congress of the International Industrial Relations Association in Paris. It was subsequently revised and up-dated to take into account recent events in both countries. The authors are grateful for the comments and suggestions of their colleagues, the editor and an anonymous referee.

Editor's note: This article was accepted by the journal on 1 June 1981 , two months before indexation was abandoned in Australia. Nonetheless, the relevance of the article remains. It is planned to print a subsequent article which will deal inter alia with the demise of the indexation system in Australia. 
of strikes and often exaggerate the economic costs involved in such actions. Thus, industrial unrest is a subject of public debate and often a central issue in national elections. These common experiences make the comparison of wage indexation policies in each country of considerable interest.

The purpose of this paper is not to provide detailed description of wage indexation arrangements within Australia and Israel in fine detail, which are readily available elsewhere (Galin, 1977 and Plowman, 1978), but rather to analyse their broad impact on industrial relations.

\section{The Australian Experience}

In Australia, the Conciliation and Arbitration Commission (as the main Federal tribunal) plays a central role in the determination and administration of wages policy. It is interesting to note, however, that the emergence of centralised wage policy machinery was largely an unplanned and unforeseen event. The tribunal was originally established for "the prevention and settlement of industrial disputes extending beyond the limits of any one state". The growth in the jurisdiction and status of the Federal tribunal was the result of early preference by unions for Federal awards, as well as a succession of liberal judicial interpretations of the Australian constitution which enabled this preference to be exercised. In 1921, the Federal tribunal, for the first time, provided automatic adjustment of wages, in accordance with changes in the cost of living, in the belief that "this would save expense, delay and uncertainty to the parties, and the time of the employers, employees and of the Court taken up at present in variations of awards to meet the cost of living" (Commonwealth Arbitration Report, 1921, p.716). This was affirmed by the full bench of the Arbitration Court in 1922 as a just and equitable system. In 1953, however, the Arbitration Court (as it was then known) abandoned the system of automatic cost of living adjustments on the grounds that they had been "an accelerating factor in the rapid increase in prices which had affected Australia notably in the years 1951 and 1952" (Commonwealth Arbitration Report, 1953, p.532).

The decision by the Conciliation and Arbitration Commission to introduce a new system of wage indexation in 1975 was the result of several factors. In 1967 the Commission abolished the long established system of a basic wage and margins in favour of a "total award". A national minimum wage, representing the lowest wage permissable for a standard work week by any employee, was introduced at the same time. During the early 1970 's the Commission sought to improve the relative structure of award wages in different industries by attempting to bring award wages more closely into line with actual wages. It met with no success, however, and by 1973-74 the contribution of national wage cases to the total increases in the weighted average wage rate for males had declined to 19 percent. Unions bargained directly with employers for large over-award payments and the Commission's role in wage determination became increasingly irrelevant (Lansbury, 1978). In the 1974 national wage case, both the Federal Labour Government and the Australian Council of Trade Unions (ACTU) argued for the reintroduction of automatic cost of living adjustment against the opposition of non-labour state governments and private employers. The unions proposed that all award wages be adjusted in line with the quarterly movement in the consumer price index (CPI) to achieve full indexation. The Australian government, on the other hand, proposed that a full percentage increase be added to all award rates up to the level of average weekly earnings, and a flat amount of increase be granted to those above that level (known as "plateau percentage indexation").

In March 1975, after a long hearing, the Commission decided to grant full percentage indexation as part of a "package" of principles. It also issued guidelines on the principles and procedures of the wage fixing system under which it believed that indexation should operate. Essentially, these guidelines stated that no wage increase could be granted without the permission of the Commission. Apart from increases in the CPI, the only grounds on which wage increases could be justified were changes in productivity or work value (such 
as the nature of work, skill and responsibility required), community catch-up, or the adjustment of rates to restore relativities. The guidelines also established the right of the Commission to determine the form of indexation at the end of each indexation period in the light of circumstances and the submissions of the parties. The Commission held quarterly indexation hearings from 1975 to 1978 but in September 1978 this was changed to half-yearly intervals. Substantial compliance with the indexation guidelines were required by both parties, especially the unions. The uncertainty surrounding the form of indexation and amount of increase, determined at each hearing, was intended to induce compliance by the parties and preserve the Commission's flexibility. The Commission has also used a variety of wage adjustments from full percentage indexation during 1975 to a mixture of mainly partial percentage and flat increases between 1976 and 1979. By establishing these guidelines, the Commission developed a new set of rules for the parties in the industrial relations system while reserving the leading role for itself. Stability in wages and centralised control of the wage system was preserved as long as the parties complied with the rules. Since the introduction of wage indexation in 1975, there have been progressive refinements of the principles; the main change being to half yearly rather than quarterly hearings. The Commission has made several attempts to achieve consensus among the parties concerning the principles of wage indexation mainly by calling them together to discuss wage fixation problems. Unfortunately, however, this desired consensus has not been achieved and growing areas of disagreement between the parties in 1979 threatened the future of the indexation system. It was argued, by June 1979, that the gap between the parties has significantly widened so that "one side (wanted) indexation with restraints while the other side (wanted) restraints without indexation". The Commission appeared to have reached the brink of announcing the abandonment of the indexation system.

At the end of 1980, the Commission suspended indexation hearings on the grounds that the parties were divided in their attitude towards the system and had not complied with its requirements. The Commission convened an inquiry into the future of the wage fixation system and invited submissions from all interested parties. Somewhat surprisingly, only the National Employers' Industrial Council (NEIC) called for a radical change to the indexation system. It proposed annual wage hearings where productivity movements, rather than the CPI, would be used as the indicator of wage movements. The NEIC also suggested that in every alternative year the Commission should conduct an inquiry into work value, conditions and relativities. On the other hand, the NEIC declared itself in full support of the centralised wage fixation with the Commission playing a central role. The Federal government argued for maintaining the twice yearly hearings with the first automatically passing on 80 percent of the CPI for the December and March quarters. At the second hearing, the remaining 20 percent plus the CPI for the June and September quarters would be considered, discounting Government induced price rises and the impact of non-compliance. The ACTU pursued its long-standing policy of full quarterly wage indexation.

In April 1981, the Commission delivered its decision on the future of wage indexation in which it proposed a new set of principles similar to those advocated by the Federal government (Australian Conciliation and Arbitration Commission, 1981). Under the new system, the Commission would hold six monthly hearings. At the March hearing, it would adjust award wages and salaries for 80 percent of the December and March quarterly movements of the CPI. The following September it would consider adjusting award wages to account for the remaining 20 percent from December and March as well as CPI movements in the June and September quarters. The Commission noted that it would also take into consideration changes in productivity and the state of the economy. Other grounds on which wage increases could be justified included changes in work value, the resolution of anomalies or inequities in the wage structure, the adjustment of allowances, service increments, first awards and extensions of existing awards to new areas of work. The most controversial aspect of the Commission's judgement was its opposition to productivity bargaining, which had been actively pursued by some unions in order to achieve a shorter working week. Although the Commission had lent its support to the concept of productiv- 
ity bargaining in 1978, it now argued that such an approach to wage fixation could no longer co-exist in a centralised system against the background of a general campaign for shorter working hours. It remains to be seen whether the Commission is able to prevent the continuation of such a development. ${ }^{1}$

\section{The Israeli Experience}

Wage indexation was introduced in Israel by the British mandatory government in 1942 on the recommendation of the "Joint Committee on Problems of Wage Adjustments". The following principles were established. First, a Cost of Living Allowance (COLA) would be paid according to changes in the CPI. Secondly, the timing and magnitude of COLA payments would be subject to negotiations. Thirdly, no allowances would be paid on wages which exceeded a given maximum or ceiling. Since that time, COLA has become a permanent feature of the Israeli industrial relations system. It has become subject to centralised collective bargaining between the Histadruth (the Israeli Federation of Labour), the Israeli employers federations, and the Israeli government.

Since wage indexation has been subject to collective bargaining, several changes have been introduced by the parties over the years. The timing of COLA payments, for example, was changed from every three to every six months in 1957, and then to every 12 months (i.e. an annual COLA payment). In 1975 it was changed back to every six months, and to every three months in 1979. In 1981, due to rapidly rising level of inflation, the government introduced monthly COLA payments. The ceiling has also been subject to frequent changes. The maximum wage above which no COLA is allowed to be paid has not been linked to any index and has been changed sporadically. Other features of the wage indexation system have also been changed. Until the 1970s, the method of calculating the CPI as a basis for the COLA had been changed many times. Since then, however, the parties have reached an agreement as to the appropriate CPI, and the indexation agreement of 1975 established an explicit partial linkage of 70 percent to the CPI. However, this was changed once more to 80 percent and in early 1981 the parties are almost ready to agree on full indexation, or 100 percent linkage to the CPI. The taxation of COLA has also been changed. Until 1975, it was agreed that COLA payments should be considered as an integral part of the wage and thus should be subject to income tax.

The indexation agreement of 1975 was supposed to set some more consistent and realistic guidelines for indexation. At the time, these guidelines seemed to be completely acceptable to all parties. The 1975 agreement established a long-term indexation agreement (for four years) under which COLA was to be paid automatically every half year. Only 70 percent of the CPI rise was to be awarded and no "ceiling" or other ad hoc adjustments were to be applied. The 1975 agreement was supposed to be a turning point in the Israeli history of indexation. The long-term agreement was supposed to prevent problems arising from frequent negotiations over COLA payments. The compensation should have been paid as soon as possible after changes in the cost of living, to avoid a gap between price rises and COLA payments. The explicit partial linkage to the CPI was intended to preserve the government's economic policy. It was also designed to avoid the payment of compensation for inflation caused by rises in import prices (which are meant to encourage export and reduce import consumption). It also seemed, at the time, that partial linkage to the CPI was preferable to complicated arrangements such as "ceiling clauses" and/or ad hoc adjustments of the CPI which cause partial linkage anyway. Since all three parties Histadruth, employers and the government - appeared to have accepted the new principles, there were high expectations that the new COLA arrangement would provide greater wage stability. These expectations were not realised, however, and the parties have found it difficult to comply with the guidelines.

Despite the automatic character of the arrangement, bargaining has continued over the

1 As we noted earlier indexation was abandoned in Australia on 31 July 1981. 
form which COLA is to take, and since 1978 there have also been negotiations concerning the timing of COLA payments. One of the main reasons for not complying with the agreement guidelines stems from the nature of COLA payments during a time of rapid inflation. The higher the inflation, the higher the part of COLA payment in any increase of wages. This makes it difficult for employers in weaker industries, to pay wage increases beyond the COLA, since the COLA payments themselves become a substantial part of the work cost. In order to avoid redundancies, especially in weaker industries, the Histadruth has not been permitted to seek wage increases beyond COLA payments. The Histadruth, therefore, has sought to demonstrate its bargaining power mainly by bargaining over the magnitude or timing of the COLA. Any automatic arrangement of COLA would thus reduce its power over its constituents and weaken its bargaining power. It should also be noted that in Israel COLA is paid as an integral part of the wage and, if paid automatically, workers would tend to forget the unions' role in this arrangement. For similar reasons, the ceiling on COLA has not been abolished. Since COLA payments have become a growing burden over time, both private employers and the government have an interest in maintaining the "ceiling" and thus reducing the "cost" of COLA. The Histadruth was willing to accept the ceiling as it did not wish to appear to be protecting the position of the higher income groups. At the same time, however, the Histadruth sought to maintain its bargaining ability over the "ceiling" issue. Thus, in effect, the indexation agreement at 1975 has not been carried out and the expectations that COLA would help to stabilise wages has not been realised.

At times of rapid and unpredictable inflation, as currently experienced in Israel, COLA becomes the central axis around which wage expectations gravitate. The workers' high expectations regarding the real wage increase from COLA result in frustration when the actual payments are made. The increase in wages due to COLA between 1975 to 1980 has been less than the increase in the CPI on some occassions, while at other times it has been more. This is due mainly to lags in adjustments. When the inflation rate is high, sixmonthly and even three-monthly CPI averaging procedures leave a gap between the total price rise and the amount of the COLA payment. As a result, it is hard to predict the rate of COLA compensation for the change in the CPI. Naturally, dissatisfaction occurs for the average wage earner when compensation is less than expected. The fact that at times the compensation is higher than the change in the CPI, does not alleviate this. Rather, it results in increased levels of expectation for the wage earner and greater disappointment when he is only partially compensated the next time. Moreover, the changes in the wage indexation system do not provide workers and employers with a stable environment in which to plan their future activities. In the face of the high and rapid inflation, which amounted to more than 130 percent in 1980 , the various changes in the indexation system seem simply to be "whistling in the dark". However, what the consequences of inflation without wage indexation would have been remains an open question.

\section{From Consensus to Disagreement:}

\section{Attitudes Towards Indexation in Australia and Israel Since 1975}

Despite the differences between their industrial relations systems and forms of wage fixation, the attitudes of the parties towards wage fixation in Australia and Israel have been similar in several respects. The unions, employers and governments in each country broadly agree that some form of wage indexation is desirable in principle. They have failed to reach a consensus, however, on the way in which indexation should be applied in practice.

\section{Union Attitudes}

In both countries, the union movement has basically favoured indexation. It has provided an "easy" way to preserve previous wage gains and to use them as a departure point from which to advance future demands. In the face of severe economic problems, indexation has provided a convenient method whereby unions could seek wage increases 
without undue damage to their public image. It has been difficult for employers or governments to oppose the preservation of employees' standards of living, even during difficult economic times. Moreover, by claiming that wage indexation enhances the stability of industrial relations, unions can demonstrate a sense of responsibility and concern for the well-being of the national economy.

The union movements in both Israel and Australia have tended to support forms of wage indexation which compensate employees for increases in the CPI but also allow for additional wage increases where it can be shown that changes in the nature or method of work have raised the level of productivity. The unions have also sought the introduction of tax indexation as well as restrictions on price increases by government. The unions fear, however, that a sustained period of less than full wage indexation will result in a reduction of real wages. They have, therefore, resisted limitations on their right to seek wage increases outside of indexation, albeit in exceptional circumstances.

\section{Employers' Attitudes}

Employers' associations in both countries have been less than enthusiastic with the way in which indexation has operated, even though they have tolerated its existence. The proliferation of employer bodies in Australia (estimated to be greater than 700) make it difficult to summarise the employers' perspective, even though the National Employers' Industry Council does officially represent Australian employers before the Arbitration Commission. Nevertheless, Australian employers share a concern with their Israeli counterparts that increases in their costs, due to wage indexation, cannot always be recovered through price increases. Employers tend to complain that wage indexation has resulted in a redistribution of income from profits to wages and thereby added to pressures on employment levels. Yet partial indexation, which results in wage restraint, can achieve wage stability and facilitate long-term planning.

\section{Government Attitudes}

Unless there had been strong government support for wage indexation at the time of its introduction, it is unlikely that it would have survived long either in Australia or Israel. When the current systems of indexation were introduced in 1975, the Labour governments then in power in both Australia and Israel sought to reduce inflation by strengthening their centralised systems of wage fixation, while also seeking to reduce the level of industrial disputation over wage issues. However, the introduction of indexation in both countries coincided with new inflationary pressures which arose from a combination of increased oil prices and a widespread economic recession throughout the Western market economies. In Australia, the government faced increases in both inflation and unemployment. Israel experienced much higher levels of inflation although less unemployment. The Labour governments which introduced the new systems of indexation in both Australia and Israel, each subsequently lost political office. Although the subsequent conservative governments, in each country, were less enthusiastic about the indexation of wages, they still support the indexation system.

\section{Wage Indexation and Industrial Relations Problems}

As noted previously, a number of industrial relations problems have arisen in connection with the operation of the wage indexation system. While many of these problems are common to Australia and Israel, others are unique to each country.

\section{Wage Increases Above Award Levels or Outside the Indexation Agreement}

The awards made by the Conciliation and Arbitration Commission in Australia, and wage levels negotiated within the "framework agreement" in Israel, only specify minimum rates. "Over-award" or "over-agreement" payments are defined as those amounts which 
employees receive in excess of the rates which are agreed under formal, centralised procedures. The gap between the awards or the agreed formal rates and the actual "paid rates" is made up by over-award or over-agreement payments. These payments are usually regarded by both the wage earners and their unions as an integral part of their wages. However, in most cases, over-award or over-agreement payments are not subject to indexation.

In the absence of indexation, the over-award part of the individual's wage does not retain its value in relation to the other part. Hence, under indexation, dissatisfaction occurs among workers who are accustomed to over-award wages and experience a decline in their differentials with respect to other workers on award wages. Recently, some Australian unions sought and received indexation of over-award payments by the Commission. This development was opposed by employers since in introduced further multiplier effects into their wage costs. Over-award payments are negotiated and achieved in accordance with the capacity of certain employers to pay. Thus, indexation of payments which are in excess of either awards or agreements result in a widening of wage differentials. This, in turn, encourages a new spiral of "catch-up" claims by unions whose members feel that their relativities have been disturbed.

\section{The Rigidity and Flexibility of Indexation Arrangements}

From an industrial relations point of view, one of the most important features of wage indexation is its flexibility. Any indexation arrangement provides mutual expectations between the parties involved. The more flexible the indexation system, the less predictable will be its operation. Conversely, a highly rigid arrangement will restrict the parties' room to manoeuver, especially in negotiations. However, since the parties have different objectives and interests in the indexation arrangement, it is necessary to provide some flexibility in order that they can bargain with each other and obtain compromises where necessary. If the system is too rigid, and restricts the parties to fixed positions, wage indexation will become ineffective in the dynamic arena of industrial relations. In Isaac's words: "rules should be formulated in a way so that they are neither too automatic, narrow and rigid, nor too broad and flexible. Industrial relations need to be accommodated by some flexibility in the rules to meet special and unforeseen circumstances, but too much play destroys the whole concept of rules". (Isaac, 1977, p.19)

In Australia, the guidelines set by the Commission for the introduction of wage indexation were quite rigid. However, the lack of automatic increases and the uncertainty as to the form of indexation which would be granted after each hearing, has introduced some flexibility into the system. Such flexibility was meant to assist the Commission in achieving a suitable compromise between the often conflicting interests of the parties. However, the parties themselves felt restricted by the guidelines and found it difficult to comply with rules established by the Commission to ensure the continuation of indexation. Similarly, the 1975 automatic indexation arrangements in Israel did not leave the parties sufficient room to manoeuver except in the collective bargaining sessions which took place once in every two years. As a result, the parties eventually abandoned the process. During periods of rapid economic change and rising inflation, as experienced by Israel in recent years, the indexation arrangements have provided neither sufficient flexibility nor a stable framework.

\section{The Politics of Wage Indexation}

In December 1975, the coalition government of the Liberal and National Country Parties was returned to Federal office in Australia after three years of rule by the Labour Party. Like their Labour predecessors, the new conservative government opposed the granting of full indexation mainly on the grounds of the depressed state of the economy. Later, it also argued that non-compliance by the unions with the indexation guidelines provided an additional reason for the Commission to limit the extent of wage increases. 
The government also sought to limit indexation hearings to once a year and, in 1978, the Commission changed from quarterly to half-yearly hearings. As part of its election campaign in 1975, the Liberal and National Country Parties promised to introduce tax indexation on obtaining government. Although the report of a Committee of Inquiry into Inflation and Taxation was published in May 1975, recommending the introduction of personal tax indexation, the government has so far failed to take major action in this field (Inflation and Taxation, 1975).

In subsequent years, relationships between the Australian government and the Commission have become increasingly strained over the issue of wage fixation, especially on occasions when the tribunal has granted full indexation. While consistently arguing for either partial or no wage increases at indexation hearings, the government has claimed that the Commission should accept economic considerations as the prime determinant of the level of any wage adjustment it awards. For its part, the Commission has replied that it is "not an arm of the Government's economic policy. It is an independent body and is required under the Act to act according to equity, good conscience and the substantial merits of the case.". Nevertheless, the Australian government is in the difficult position where it is constrained by the constitution from being able to control wages and prices, and must adjust to the Commission's decisions. Needless to say, however, the Commission usually pays considerable attention to the Australian government's views, while vigorously defending its independent position.

When the conservative Licud government assumed office in Israel during 1977, it did not immediately challenge the indexation system which had been curtured by its Labour predecessor. Wage indexation in Israel is based upon an agreement reached between the Histadruth and the Israeli Employers' Federation, which is made initially in the private sector but is subject to an extension order by the government which ensures that it is applied to the whole economy. Early in 1980, the Licud government proposed that full COLA payments be made to wage earners each month subject to the condition that no other wage demands be presented, except those based upon increased productivity. Both the Histadruth and the Employers had reservations about the proposal but raised no formal objections. Observers believe, however, that the new arrangements are too rigid and that the parties are unlikely to give total adherence to the government's policy. Nevertheless, while the government in Israel (as in Australia) cannot force either the unions or employers to comply with its wage policies, it plays a most influential role in determining the framework within which the parties are required to operate.

\section{Indexation and Industrial Unrest}

The past decade in both Israel and Australia has been marked by increased industrial disputation. The number of days lost due to strikes, per thousand people employed, has been far greater in Australia than Israel. Unfortunately, however, the methods of defining and collecting statistics on strikes differ considerably between the two countries and caution must be exercised when seeking to make comparisons. There were also significant domestic issues which occurred within both countries during the past decade; wars in Israel and political strikes associated with a change in government in Australia, which distorted the strike statistics. Nevertheless it would appear that there has been greater stability in the industrial relations environment within both countries since the introduction of their current systems of indexation in 1975.

It is difficult to discern any clear trends in terms of the nature of strike activity under indexation. The average length of a strike in both Australia and Israel has oscillated between two and three days during the past decade. It is interesting to note, however, that about two-thirds of strikes are typically three days or less in both Australia and Israel despite the fact that Australia has compulsory arbitration while in Israel it is voluntary.

The average man days lost per strike since the introduction of current forms of indexation indicates opposite trends in Australia and Israel. There has been a dramatic rise in man 
days lost per strike in Israel since 1974 despite indexation, although it has not yet surpassed the record levels of 1973. In Australia, the trend has been in the opposite direction. A sharp increase in the average man days lost per strike in 1973 was followed by a decline. This trend, however, appears to have occurred despite indexation rather than because of its operation. Indeed, the man days lost due to strikes have been rising again since the 1970s.

The average number of persons involved in each strike since the introduction of indexation also appears to follow opposite trends in Australia and Israel. Within Israel, the average number of persons involved in each strike has increased steadily since 1974. The only exception to this trend was a slight decline between 1975 and 1976, which may have indicated a temporary effect created by indexation. In Australia, the average number of strikers involved in each strike increased over 1975 and 1976 but declined thereafter. The high figures for 1976 were due to the one-day national strike called in protest at changes by the newly elected Liberal National Country Party government to the national health system. Since the late 1970s however, the figures appear to be rising again.

Finally, the causes of industrial disputes since 1975 indicates further differences between Australia and Israel. Comparisons based on these data are difficult as the information published in each country is imprecise and the definitions of terms vary considerably (Bentley, 1980). Nevertheless, there appears to have been an increase in the percentage of disputes due principally to wages and hours in Israel since the current form of indexation was introduced. While the percentage of disputes over working conditions and managerial policy has increased at an even faster rate between 1975 and 1977, it is still less than the proportion due to wage issues. The analysis is complicated, however, by the large proportion of strikes due to "other causes". In Australia, there was a marked decline in the proportion of disputes due mainly to wage issues between 1975 and 1977 and an increase in disputes over conditions and managerial policy. It would appear, from these figures, that indexation in Australia had some dampening effect on wage demands, although they still account for more than half of the total man days lost due to strikes. In Israel, with the possible exception of 1976, indexation did not appear to reduce the proportion of wage related strikes.

\section{Conclusions}

The comparison of the effects of wage indexation on industrial relations in different countries, such as Israel and Australia, is difficult. This is due to a variety of factors; differ= ences in the systems of industrial relations in each country, the economic and political environment, and the forms of indexation which are practised. Nevertheless, as noted in this paper, there are a number of interesting similarities between Australia and Israel. Both countries introduced their recent systems of wage indexation in 1975 and, although the specific arrangements varied considerably, there were important common features. Recently there has been considerable dissatisfaction among most parties with the operation of wage indexation systems in each country. Several problem areas common to indexation in the two countries have been identified and discussed in this paper. They include wage increases granted above award levels or outside the indexation agreement, the rigidity and flexibility of indexation arrangements, the political issues surrounding indexation, and the impact of indexation on levels of industrial unrest. It is clear, moreover, that wage indexation has not provided a panacea for economic or industrial relations in either Israel or Australia.

In both Australia and Israel the government has played a leading if not dominant role in the indexation system. In Australia, the Conciliation and Arbitration Commission has administered the system and set guidelines for its continued operation and indeed it is clear that the introduction of indexation has restored authority to the Commission in the field of wage determination. Yet the Commission relies upon the willingness of unions and employers to abide by its decisions. Above all, the Commission is strongly influenced by government economic policy, while seeking to preserve its independent and primary role 
of preventing and settling industrial disputes. Although the Australian government has chided the Commission for not handing-down wage decisions which are consistent with its economic policy, changes in the operations of the indexation system have followed the broad direction of government submissions. Similarly, in Israel, the government of the day has been the dominant influence on the operation of indexation through its power over taxation and its ability to issue or withhold "extension orders" on agreements made between the Histadruth and the employers.

A major difference between the operation of indexation in Australia and Israel has been in terms of flexibility within each system. In Australia, the guidelines set by the Commission established clear but strict parameters for unions seeking wage increases. The Commission retained sufficient flexibility for itself, however, to ensure that the system survived. Various safety valves were used to grant unions increases due to changes in "work value" or "wage anomalies" and thereby reduce pressures on the system. By contrast, the parties in Israel were afforded less flexibility and were restricted to biennial collective bargaining sessions in order to obtain changes in the operation of the indexation system.
ments outside indexation, which unions and employers were forced to reach ad hoc agreements outside indexation, which undermined the system.

Although the major parties in both the Australian and Israeli industrial relations sytems have all agreed at various times on the benefits to be gained from wage indexation in principle, they have found it difficult to agree on how the system should operate in practice. In both countries all parties have blamed each other for the failure of indexation to fulfil their highest hopes. In part, this is due to unrealistic expectations which were raised by some of the advocates for indexation. It also reflects, however, basic conflicts of interest which exist between the parties in industrial relations. While the Australian and Israeli experiences provide a cautionary lesson in the application of wage indexation policies, they also underline some important requirements for success. First, there needs to be substantial consensus among the parties concerning not only the principles but also on the ground rules of how indexation is to be applied. Secondly, there need to be clear guidelines on the operation of indexation combined with sufficient internal flexibility to enable the parties to bargain within an agreed framework. Thirdly, any system of indexation needs to be reviewed on a regular basis to ensure that it adequately serves the needs of all the parties involved. Certainly, the mere existence of a system of wage indexation, as witnessed in both Israel and Australia, has not been sufficient by itself to ensure wage stability or to reduce industrial disputation.

\section{References}

Australian Conciliation and Arbitration Commission (1981) Report of the inquiry into wage fixing principles.

Bentley, P. (1980) Recent strike behaviour in Australia: causes and responses. In G.W. Ford; J.M. Hearn; and R.D. Lansbury (Eds) Australian labour relations Melbourne, Macmillan, pp $21-49$.

Commonwealth arbitration reports (1921), 15 (704).

Commonwealth arbitration reports (1953), 77 (477)

Galin, A. (1977) Wage indexation and industrial relations in Israel Labour and society 2: 301-310.

Inflation and taxation (1975) Report of the committee of inquiry into inflation and taxation, Canberra, AGPS (the Mathews report).

Isaac, J.E. (1977) Wage determination and economic policy The Australian economic review.

Lansbury, R.D. (1978) The return to arbitration: recent trends in dispute settlement and wages policy in Australia International labour review 117: 611-624.

Plowman, D. (1978) Wage indexation: the Australian experience New Zealand journal of industrial relations 3: 105-117. 